\section{Allergy to Black Bass Fin and Carp}

De Aramburu Mera $\mathrm{T}^{1}$, Cimbollek $\mathrm{S}^{1}$, Pineda De la Losa $\mathrm{F}^{2}$, Castillo Fernández $\mathrm{M}^{2}$

${ }^{1}$ Department of Allergology, University Hospital Virgen del Rocio, Seville, Spain

${ }^{2}$ Diater, R\&D Department, Madrid, Spain

J Investig Allergol Clin Immunol 2020; Vol. 30(3): 193-194 doi: $10.18176 /$ jiaci.0472

Key words: Black bass. Carp. Apolipoprotein B. B-Actin.

Palabras clave: Lubina negra. Carpa. Apolipoproteína B. B-actina.

Fish allergy is a pathological, IgE-mediated immune response to specific fish proteins. Sensitization is mainly via exposure to the allergen the gastrointestinal tract, as well as via exposure to fish aeroallergens in the respiratory tract or through skin contact $[1,2]$. Most fish-allergic patients show marked clinically relevant cross-reactivity, while a minority of patients experience selective allergy to specific fish species, with good tolerance to other fish families [3].

Black bass (Micropterus salmoides) is originally from North America and was introduced in Spain in 1955 for recreational fishing. Like carp (Cyprinidae), it is predominant in freshwater fishing.

We present a case of contact allergy due to 2 different proteins of black bass and carp.

A 24-year-old recreational angler with a history of rhinoconjunctivitis and bronchial asthma due to sensitization to house dust mites and olive pollen experienced conjunctival erythema, nasal block-age, and dyspnea as a result of contact with cyprinids. Therefore, when he went fishing, he premedicated with oral antihistamines and salbutamol and used gloves. He was referred to our unit after an episode of hand edema and upper ipsilateral limb edema accompanied by generalized urticaria resulting from accidental puncture with the dorsal fin of a black bass. He presented no additional symptoms. The episode resolved spontaneously in a few minutes. He subsequently handled black bass without incident and tolerated fish intake.

The patient underwent skin prick tests (SPTs) for the most common aeroallergens in our area (mites, pollens, molds, latex, Anisakis simplex, and dander [cat, dog, and horse]) and also for hake and cod. His results were positive to Dermatophagoides pteronyssinus, Glycyphagus domesticus, and Olea europaea pollen.

We performed prick-by-prick tests with carp and black bass. The results were positive, with wheals measuring $11 \mathrm{~mm}$ and $7 \mathrm{~mm}$, respectively.

Proteins from different parts of raw black bass and carp (fin, head, body, and skin) were extracted with phosphatebuffered saline (PBS) and then homogenized using a mortar and pestle at $5 \pm 3^{\circ} \mathrm{C}$. The mix remained homogenized until the greatest possible content was released. The homogenate was shaken magnetically before being sieved to remove nonsoluble material. The extract was then centrifuged, filtered, dialyzed against deionized water, and lyophilized.

Proteins were separated by SDS-PAGE in $15 \%$ polyacrylamide gels, which were loaded at $10 \mu \mathrm{g} /$ well according to the method described by Laemmli [4] Subsequently, the patient's diluted serum (1:5) was incubated with the proteins $(1 \mu \mathrm{g} / \mathrm{well})$, which were transferred onto a polyvinylidene fluoride (PVDF) membrane as previously described [5]. After blocking with $0.5 \%$ PBS Tween- 20 buffer, the membrane was incubated overnight with the patient's serum. A PVDF membrane containing the same extract was incubated with $0.5 \%$ PBS Tween-20 buffer and with serum from a nonatopic individual as a negative control. The PVDF membranes were incubated with mouse antihuman $\mathrm{IgE} \mathrm{Fc-}$ HRP (Southern Biotech). Reactive bands were detected using enhanced chemiluminescence following the manufacturer's instructions (Western Lightning Plus-ECL, Perkin Elmer).

The Western blot analysis revealed IgE-binding bands for several proteins weighing between 45 and $25 \mathrm{kDa}$ in the black bass fin, as well as a $25-\mathrm{kDa}$ protein in all of the carp parts studied. While the molecular weight was similar to that of the black bass protein, the intensities varied, probably owing to differences in content (Figure).

Multiple IgE-binding bands have been detected in fish extracts, but parvalbumins are considered to be the most clinically relevant allergen [3,6,7]. Parvalbumin is an acidic calcium-binding protein of 113 amino acids that is very common in fish muscle. It has a low molecular weight of approximately $10-12 \mathrm{kDa}[8,9]$. It is highly stable, resistant to proteolysis, and can be transported in aerosols and cooking vapors [2]. In addition to the parvalbumins, several other fish proteins (eg, enolases, aldolases, and fish gelatin) have been identified as major fish allergens.

In the present case, we identified 2 previously undescribed allergenic proteins in 2 fish species. In the case of carp, we found an apolipoprotein B of $27.5 \mathrm{kDa}$ with sequence coverage of $14 \%$ by peptide mass fingerprinting in all the parts studied. Sensitization seemed to be through contact with the animal and caused respiratory symptoms (rhinoconjunctival and asthma) and skin symptoms (urticaria in the contact area). In the case of black bass, however, the protein identified was a $\beta$-actin with a molecular mass of $42 \mathrm{kDa}$ and sequence coverage of $38 \%$, again using peptide mass fingerprinting. This protein

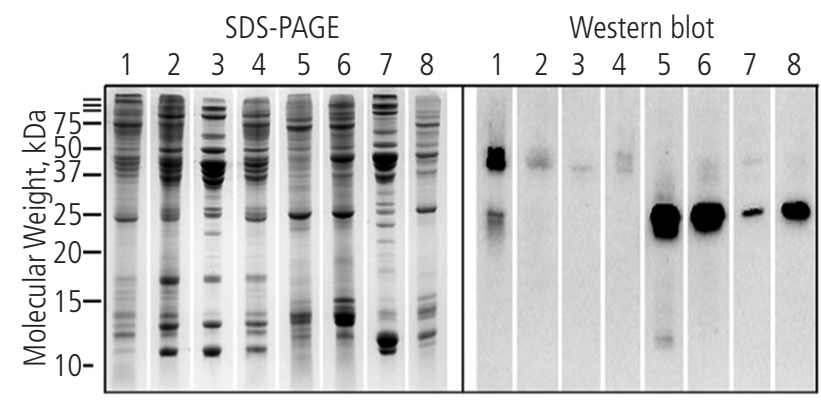

Figure. SDS-PAGE and Western blot: Lane 1, black bass fin; Lane 2, black bass head; Lane 3, black bass body; Lane 4, black bass skin; Lane 5, carp fin; Lane 6, carp head; Lane 7, carp body; Lane 8, skin. 
was present exclusively in the fin. Furthermore, sensitization was by contact, and the only manifestations were cutaneous.

Cutaneous symptoms have previously been reported after contact with raw fish. Shimojo et al [1] provide data on a patient who presented with itching and urticaria on the forearms after contact with raw conger. An immunoblot study revealed IgE against $\alpha$-actin-3 of approximately $110 \mathrm{kDa}$. This protein has been described as a cross-reactive protein in house dust mites and in shrimp [10]. In the present case, contact with carp induced not only cutaneous symptoms, but also a systemic reaction. To our knowledge, this is the first report of anaphylaxis due to cutaneous contact with cyprinids, although there are reports of anaphylactic reactions to seafood [3]. The allergenic proteins have a lower molecular weight than in the previously mentioned case. Furthermore, the patient reacted to 2 different fish species and allergens.

In conclusion, we identified 2 proteins with $\operatorname{IgE}$ binding capacity that had not been previously described in different species of fish. Both bands could correspond to a new fish allergen family, although further characterization is necessary.

\section{Funding}

The authors declare that no funding was received for the present study.

\section{Conflicts of Interest}

The authors declare that they have no conflicts of interest.

\section{References}

1. Shimojo N, Yagami A, Nakamura M, Nagai A, Matsunaga K. Occupational fish allergy caused by percutaneous sensitization with alpha-actin-3. Contact Dermatitis. 2017;76:322-3.

2. Onesimo R, Giorgio V, Pill S, Monaco S, Sopo SM. Isolated contact urticaria caused by immunoglobulin E-mediated fish allergy. Isr Med Assoc J. 2012;14:11-3.

3. Kourani E, Corazza F, Michel O, Doyen V. What we know about fish allergy by the end of the decade? J Investig Allergol Clin Immunol. 2019;11:0. doi: 10.18176/jiaci.0381

4. Laemmli UK. Cleavage of structural proteins during the assembly of the head of bacteriophage T4. Nature. 1970;227(5259):680-5.

5. Towbin H, Staehelin T, Gordon J. Electrophoretic transfer of proteins from polyacrylamide gels to nitrocellulose sheets: procedure and some applications. Proc Natl Acad Sci USA. 1979;76(9):4350-4

6. Van Do T, Elsayed S, Florvaag E, Hordvik I, Endresen C. Allergy to fish parvalbumins: Studies on the cross-reactivity of allergens from 9 commonly consumed fish. J Allergy Clin Immunol. 2005;116:1314-20.

7. Moonesinghe $H$, Mackenzie $H$, Venter $C$, Kilburn S, Turner $P$, Weir $K$, et al. Prevalence of fish and shellfish allergy: A systematic review. Ann Allergy Asthma Immunol. 2016;117:264-72.

8. Sharp MF, Lopata AL. Fish allergy: in review. Clin Allergy Immunol. 2014;46(3):258-71.
9. Kuehn A, Swoboda I, Arumugam K, Hilger C, Hentges F. Fish allergens at a glance: variable allergenicity of parvalbumins, the major fish allergens. Front Immunol. 2014;5:179.

10. Gámez C, Zafra M, Boquete M, Sanz V, Mazzeo C, Ibáñez $M D$, et al. New shrimp lgE-binding proteins involved in miteseafood cross-reactivity. Mol Nutr Food Res. 2014;58:191525.

Manuscript received May 16, 2019; accepted for publication December 9, 2019.

Teresa De Aramburu Mera

Department of Allergology University Hospital "Virgen del Rocío" Manuel Siurot 41013 Sevilla, Spain E-mail: teresadearamburumera@gmail.com 